\title{
Nyheter från Fakulteten för konst och humaniora
}

Under det senaste dryga året har flera avhandlingar lagts fram av doktorander vid Fakulteten för konst och humaniora (Linnéuniversitetet), eller av personer knutna till denna fakultet.

Linnéuniversitetet har fått sin första doktorsavhandling i ortnamnsforskning. Den 23 oktober 2015 försvarade Ola Svensson sin avhandling Nämnda ting men glömda. Ortnamn, landskap och rättsutövning. Opponent var docent Per Vikstrand, Institutet för språk och folkminnen. Avhandlingen syftar dels till att samla in, avgränsa och beskriva de ortnamn i Skåne som är förknippade med rättsutövning, dels att beskriva de platser som dessa namnger samt de rättskretsar - oftast härader - vilkas centra rättplatserna har varit. Ola Svensson har för övrigt fått ett stipendium från Kungl. Gustav Adolfs Akademien för svensk folkkultur för sitt arbete. Den intresserade kan ladda ned det direkt från Diva, se: http://lnu.divaportal.org/smash/get/diva2:858241/FULLTEXT06.pdf.

Emilie Wellfelt lade fram sin avhandling i historia 23 september 2016, med titeln Historyscapes in Alor: Approaching indigenous histories in Eastern Indonesia. Opponent var professor Timo Kaartinen, Helsingfors. Avhandlingen söker nya vägar för att närma sig lokala kulturers historia och fokuserar på ön Alor i östra Indonesien. Alor kom under full nederländsk kolonial kontroll på ett sent stadium i början av 1900-talet. Traditionellt var ön uppdelad i flera olika småriken respektive språkområden. I sin analys av av inhemskt historieanvändande använder sig Wellfelt av begreppet historyscape vilket ger tillfälle att diskutera bevarandet, skapandet och kommunicerandet av historia, samt att se hur historia förstås och förmedlas på olika komplexa sätt. Avhandlingen bygger på en omfattande insamling av muntliga traditioner på Alor och går i detalj igenom historyscapes i fyra regioner: Östalor, Centralbryggan, Abuiområdet samt Fågelhuvudet/Västalor. Materialet diskuteras ingående och jämförs med externa, framför allt koloniala historiska data. Undersökningen visar på den vikt som människor lägger vid historier om det förgångna, även i småskaliga och icke-skriftliga kulturer, och det överflöd av berättelser med historiska anspråk som framkommer så snart forskaren börjar lyssna. För mer information om avhandlingen, se http://lnu.diva-portal.org/smash/record.jsf?pid=diva2\%3A971262\&dswid=-3646.

Samma datum, den 23 september 2016, försvarade Hanna Gladh sin avhandling i engelska, Keep V-ing: Aspectuality and event structure. Opponent var professor Östen Dahl, Stockholms universitet. Syftet med hennes studie är att tillhandahålla en utförlig redogörelse för meningen i "keep V-ing"-konstruktioner. Till exempel: (a.) "Mary kept winning (again and again)". (b.) "John kept running (for another ten minutes)". På basis av en systematisk studie av kombinationer av "keep" med predikat i olika aktionsarter påvisas att "keep" kan ge upphov till två olika läsningar vilka delar den övergripande meningen "continued activity". Genom att jämföra "keep V-ing" med den progressiva konstruktionen "be V-ing" (som "John was building the house") samt med två andra kontinuitiva konstruktioner, "continue V-ing" (som "John continued building the house") och "V on" (som "John ran on") visas att "keep" 
kan ändra ett teliskt predikat till en ateliskt läsning genom att täcka hela händelsen, men ej kan täcka en intern del av en telisk händelse. Dessutom, i motsats till "continue V-ing" och "V on" så beskriver "keep V-ing" inte nödvändigtvis en händelse som redan initierats. Avhandlingen kan läsas på länken http://www.diva-portal.org/smash/get/diva2:954250/FULLTEXT02.pdf.

Pia Bygdéus är universitetslektor i musikpedagogik vid Linnéuniversitetet och därtill är hon aktiv frilansande musiker, pianist, dirigent, repetitör och musikproducent på P2Live. Hon försvarade 2015 sin avhandling Medierande verktyg $i$ körledarpraktik - en studie av arbetssätt och handling $i$ körledning med barn och unga vid Lunds universitet. Alla vet vad körsång är och vad körledaren gör - men vad gör körledaren och hur gör körledaren? Körledning innebär en stor variation av inre/yttre förhandlingar respektive omförhandlingar av arbetssätt och medierande verktyg. Studien är longitudinell och av kvalitativ karaktär. Det empiriska materialet består av observationer, halvstrukturerade intervjuer, fokussamtal, enskilda eftersamtal, reflekterat skrivande för körledare såväl som forskare. Relationell förmåga återspeglas i psykologiska aspekter av använda verktyg, hur kördirigering sker, vad som förmedlas och hur. Pedagogik och konstnärlighet är sammanflätat, människan tolkar musikaliska signaler utan prat, och när inre och yttre kulturella verktyg samverkar kan en konstnärlig upplevelse inträffa. Kören som instrument är och blir till ett medierande verktyg för körledarens musikaliska intentioner. Med reflektion som verktyg är varje stund i en musikalisk praktik ett pågående arbete för körledaren, såväl före, under som efter en gemensam aktivitet. Reflektionen blir på så vis ett verktyg som driver arbetet framåt. Avhandlingen finns att läsa på länken

https://lup.lub.lu.se/search/publication?q=\%22bygdéus\%22.

Andreas Johansson, lärare i religionsvetenskap vid Linnéuniversitetet, lade fram sin avhandling, Pragmatic Muslim politics. The case of Sri Lanka Muslim Congress vid Lunds universitet 2016. Opponent var professor Susanne Olsson, Stockholms universitet. Här diskuteras och analyseras användandet av islamska termer och symboler i det politiska partiet Sri Lanka Muslim Congress (SLMC). Idag är de invecklade, överlappande och motsägelsefulla relationerna mellan religion och politik ett dynamiskt forskarfält. Forskningen lider dock av två stor brister. Den forskningen som utförs inom statsvetenskapen saknar ofta djupare förståelse för religionens kraft och verkan i såväl individens liv som i samhällets funktion. Forskningen har koncentrerat sig på frågor som berört varför partiet blivit så framgångsrikt. Religionen nämns som en faktor, men de har inte gått djupare in på vilka begrepp som används och varför. Johansson har därför valt att delvis analysera samma material som tidigare forskning har använt för att påvisa att olika religiösa attribut (språk och symboler) är närvarade i SLMC diskurs. Andreas Johansson avhandling om det ledande muslimska partiet på Sri Lanka är i detta sammanhang viktig inte bara eftersom Johanssons intervjuer av partiets centrala politiker och studier av partiets officiella texter ger oss ny kunskap om det religiösa och politiska läget på Sri Lanka, utan även eftersom den ger en djupare förståelse för en religiös (därtill muslimsk) rörelse vars politiska agenda ingalunda är fundamentalistisk, utan "pragmatisk". Avhandlingen nås via länken

https://lucris.lub.lu.se/ws/files/7528313/Andreas_Johansson_Pramatic_Muslim_Politics_the Case_of_Sri_Lanka_Muslim_Congress.pdf. 
Förutom avhandlingar kan ett par andra aktuella publikationer nämnas. Magnus Eriksson, lektor i kreativt skrivande vid Fakulteten för konst och humaniora, har redigerat antologin Den befriade människan (Stockholm: Trolltrumma förlag 2016) som utgör Pär Lagerkvistsamfundets årsskrift. Boken innehåller sju artiklar och en recension skrivna av akademiker, journalister, dramatiker och skönlitterära författare. Ämnena spänner över olika aspekter av Lagerkvists livs- och människosyn, och även hans egendomliga frånvaro från dagens svenska teaterscener. Därtill har Christer Knutsson sammanställt en Lagerkvistbibliografi för åren 1990-1999.

Från Fakulteten för konst och humaniora kommer också antologin Möten med mening. Ämnesdidaktiska fallstudier i konst och humaniora (2016, red. Karin L. Eriksson). Den består av femton ämnesdidaktiska fallstudier som alla kretsar runt frågor om möten, mening och meningsskapande. I antologins första del - "Att erfara mening" - ligger fokus på elevers och studenters möten med olika ämnen och discipliner. I den andra delen - Att iscensätta mening - får läsaren exempel på hur meningsfulla möten kan gestaltas i undervisningen. Artiklarna är skrivna av forskare inom Centrum för ämnesdidaktisk forskning inom konst och humaniora vid Linnéuniversitetet (C̈̈HL), en centrumbildning vars syfte är bland annat att stärka den ämnesdidaktiska forskningsmiljön inom Fakulteten för konst och humaniora. Antologin är en del i detta arbete, och med fallstudier från flera humanistiska och estetiska ämnesområden, ger den exempel på hur olika frågeställningar och problemområden kan överföras mellan olika ämnesområden och därigenom berika varandra. Antologin vänder sig både till ämneslärarstudenter och lärarutbildare som till ett vidare forskningsfält.

Tommy Gustafsson, historiker och professor i filmvetenskap vid fakulteten, har tagit initiativ till en podcast, Humpodd. Den nya serien av poddar innehåller samtal med forskarpersonligheter vid Linnéuniversitetet, i första hand Fakulteten för konst och humaniora. Tanken med podden är att visa på den rika flora av intressanta forskningsområden som idag finns inom humanistiska och konstnärliga ämnen på universitetet. Hittills har sex poddar publicerats på nätet om så skiftande ämnen som barnfilm, postkolonialitet och språkbruk vid toalettbesök. Humpodd kan nås på webbadressen

https://humpodd.wordpress.com/.

\section{Hans Hägerdal}

